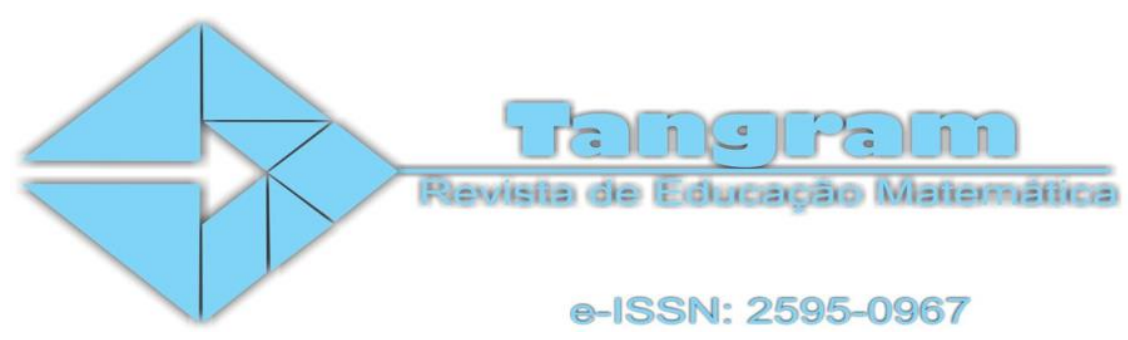

\title{
Apresentação: interdisciplinariedade, tecnologias e estágio supervisionado
}

Esta edição conta com 9 trabalhos organizados em artigos investigativos, iniciação científica e relatos de experiência. Temos 6 artigos científicos, 5 de diferentes instituições brasileiras (Pontifícia Universidade Católica de São Paulo, Universidade Federal Fluminense, Instituto Federal do Espírito Santo, Instituto Federal de Educação, Ciência e Tecnologia de Goiás, Universidade do Estado de Mato Grosso) e um artigo estrangeiro oriundo das universidades (Universidade Rey Juan Carlos e Universidade de Zaragoza).

Divulgamos ainda uma iniciação científica do estado de Minas Gerais , desenvolvido na Universidade Federal de Minas Gerais .

Os dois relatos de experiência um brasileiro oriundo do estado da Bahia desenvolvido na Universidade do Estado da Bahia e outro estrangeiro desenvolvido na Espanha na Universidade de Oviedo.

De modo geral, observamos que os artigos apresentam investigações que poderão aprimorar os aspectos relevantes ao ensino interdisciplinar, assim como ao uso das tecnologias e as experiencias sobre os estagios supervisionados.

Vislumbramos que estas investigações proporcionarão reflexões sobre diferentes práticas de ensino e auxiliarão no planejamento dos docentes para as suas ações em sala de aula.

Percebemos o quanto é significativo a temática e esperamos que apreciem.

Tangram - Revista de Educação Matemática, Dourados - MS - v.3 n.3, pp. 01-02 (2020)

Este obra está licenciada com uma Licença Creative Commons Atribuição-NãoComercial-CompartilhaIgual 3.0 Brasil. 


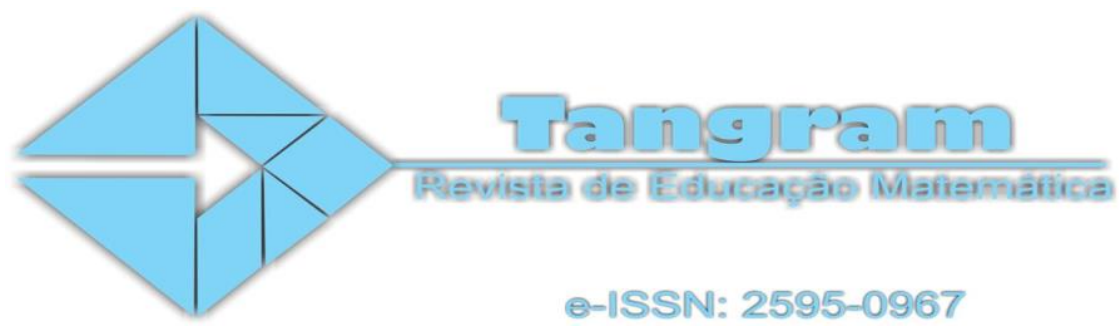

Diante do exposto, desejamos uma boa leitura à todos.

Editores

Edvonete Souza de Alencar

Aldrin Cleyde da Cunha

Tiago Dziekaniak Figueiredo

Adriana Fátima de Souza Miola

Tangram - Revista de Educação Matemática, Dourados - MS - v.3 n.3, pp. 01-02 (2020)

Este obra está licenciada com uma Licença Creative Commons Atribuição-NãoComercial-CompartilhaIgual 3.0 Brasil. 